\title{
The Effects of Artemia Cyst Harvesting on the Salt Lake Ecosystem
}

\author{
Liudmila I. Litvinenko $0^{\mathrm{a}, \mathrm{b} *}$, \\ Aleksander I. Litvinenko ${ }^{\mathrm{b}}$, Elena G. Boyko ${ }^{\mathrm{b}}$, \\ Kirill V. Kutsanov and Marina A. Korentovich ${ }^{\mathrm{b}}$ \\ a'Tyumen Branch of FSBSI "VNIRO" ("Gosrybcentr") \\ Tyumen, Russian Federation \\ ${ }^{b}$ State Agrarian University of the Northern-Trans-Urals \\ Tyumen, Russian Federation
}

\begin{abstract}
In Russia, the main stocks of Artemia cysts and cyst harvesting activities are concentrated in Western Siberia. About 1,100 tons of cysts are harvested annually, including 180 tons in the Kurgan Region and 140 tons from Medvezhye Lake (about $2 \%$ of their world harvest). The purpose of this study was to determine the degree of influence of Artemia cyst harvesting on the ecosystem of a salt lake in a case study of Medvezhye Lake. The main trophic components of the ecosystem - phytoplankton, zooplankton, and zoobenthos - were analyzed. The salinity of the brine of Medvezhye Lake varied between 110 and $320 \mathrm{~g} / \mathrm{dm}^{3}$ in different years. Phytoplankton in the lake function throughout the year. They are characterized by small cell sizes, low biomass $(0.76 \pm 0.24 \mathrm{mg} / \mathrm{L})$ and daily production $\left(1.03 \pm 0.18 \mathrm{mgO}_{2} / \mathrm{L}\right.$ or $\left.0.3 \pm 0.05 \mathrm{gC} / \mathrm{m}^{2}\right)$, and high levels of $\mathrm{A} / \mathrm{B}$ and $\mathrm{P} / \mathrm{B}$ coefficients. Zooplankton and zoobenthos are represented mainly by Artemia. The biomass of Artemia shrimp reached $21.9 \pm 3.2 \mathrm{mg} / \mathrm{L}(219 \mathrm{~kg} / \mathrm{ha})$ on average during 1995-2018. During this period, the stock of cysts formed annually in the lake was $114.5 \pm 14.3 \mathrm{~kg} / \mathrm{ha}$; the harvest was $23.7 \pm 3.0 \mathrm{~kg} / \mathrm{ha}$ ( $21 \%$ of the stock). The main components of the ecosystem phytoplankton - Artemia shrimp - Artemia cysts - were produced annually in the following proportions: $8390: 2678: 115 \mathrm{~kg} / \mathrm{ha} \cdot y e a r(75: 24: 1 \%)$. The removal of $23.7 \mathrm{~kg} / \mathrm{ha}$ of the cysts $(0.22 \%$ of the production of all components) from the lake is negligible compared to the other components of the ecosystem. The residual density of cysts after harvesting, which is necessary for the reproduction of the Artemia population for the next season during the $1 \mathrm{st}$ generation, is $10 \mathrm{~kg} / \mathrm{ha}$. Averaged data indicate that the amount of Artemia cysts left in the ecosystem of Medvezhye Lake after cyst harvesting is $91 \mathrm{~kg} / \mathrm{ha}$, i.e. 9 times greater than the minimum required density. The
\end{abstract}

\footnotetext{
(C) Siberian Federal University. All rights reserved

This work is licensed under a Creative Commons Attribution-NonCommercial 4.0 International License (CC BY-NC 4.0).

* Corresponding author E-mail address: litvinenko_li@mail.ru

ORCID: 0000-0002-8189-5226 (Litvinenko L.); 0000-0002-0632-9283 (Kutsanov K.); 0000-0002-6524-196X (Boyko E.) 
results reported in the present study indicate that the current level of cyst harvesting cannot have any significant impact on the ecosystem of the hypersaline lake.

Keywords: Artemia, cysts, brine shrimp, phytoplankton, harvest, salt lakes.

Citation: Litvinenko L.I., Litvinenko A.I., Boyko E.G., Kutsanov K.V., Korentovich M.A. The effects of Artemia cyst harvesting on the salt lake ecosystem. J. Sib. Fed. Univ. Biol., 2020, 13(4), 348-367. DOI: 10.17516/1997-1389-0333

\title{
Влияние промысла цист артемии \\ на экосистему гипергалинного озера
}

\author{
Л.И. Литвиненко ${ }^{a, \sigma}$, А.И. Литвиненко ${ }^{\sigma}$, \\ Е.Г. Бойко ${ }^{\tilde{\sigma}}$, К.В. Куцанов ${ }^{\mathrm{a}}$, М.А. Корентович ${ }^{\boldsymbol{\sigma}}$ \\ ${ }^{a}$ Тюменский филиал ФГБНУ «ВНИРО» («Госрыбиентр») \\ Российская Федерация, Тюмень \\ ${ }^{\circ}$ Государственный аграрный университет Северного Зауралья \\ Российская Федерация, Тюмень
}

\begin{abstract}
Аннотация. В России основные запасы цист артемии и их промысел сосредоточены в Западной Сибири, где, согласно многолетней статистике, в среднем ежегодно добывается около 1100 т цист, из них в Курганской области - 180 т, на оз. Медвежье - 140 т (около $2 \%$ от мирового промысла). Целью этого исследования было определить степень влияния промысла цист артемии на экосистему гипергалинного водоема на примере наиболее изученного оз. Медвежье. В статье проанализированы главные трофические компоненты гипергалинной экосистемы: фитопланктон, зоопланктон и зообентос. Соленость рапы озера в разные годы составляла 110-320 г/дм³. Фитопланктон в озере функционирует круглый год, характеризуется мелкоклеточностью, низкими показателями биомассы $(0,76 \pm 0,24$ мг/л)

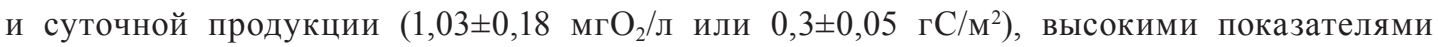
A/B- и Р/В-коэффициентов. Зоопланктон и зообентос представлены в основном

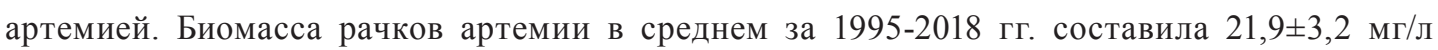
(219 кг/га). За этот период в озере ежегодно формировались запасы цист в среднем в объеме $114,5 \pm 14,3$ кг/га, вылов составлял $23,7 \pm 3,0$ кг/га (21 \% от запасов). В целом по озеру годовая продукция главных компонент экосистемы фитопланктон - рачки артемии - цисты артемии находилась в следующем соотношении - 8390:2678:115 кг/га·год (75:24:1 \%). Изъятие цист из озера в количестве 23,7 кг/га (0,22 \% от продукции всех компонентов), ничтожно мало по сравнению с остальными составляющими биоценоза. Остаточная после промысла плотность цист, необходимая для воспроизводства популяции артемии на следующий сезон в период 1-й генерации, составляет 10 кг/га. Усредненные данные показывают, что в биоценозе оз. Медвежье после промысла остается 91 кг/га цист, т.е. в 9 раз больше указанной плотности. Данные, представленные в статье, свидетельствуют об отсутствии

$$
-349-
$$


какого-либо значимого влияния на экосистему гипергалинного озера существующего на данный момент уровня промысла цист.

Ключевые слова: артемия, цисты, рачки, фитопланктон, промысел, соленые озера.

Цитирование: Литвиненко, Л.И. Влияние промысла цист артемии на экосистему гипергалинного озера / Л.И. Литвиненко, А.И. Литвиненко, Е.Г. Бойко, К.В. Куцанов, М.А. Корентович // Журн. Сиб. федер. ун-та. Биология, 2020. 13(4). C. 348-367. DOI: 10.17516/1997-1389-0333

\section{Введение}

Проблема комплексного устойчивого использования водных ресурсов, в том числе ресурсов гипергалинных водоемов (минеральные соли, лечебные грязи, цисты и рачки артемии, рекреация), актуальна во всем мире (Озеро Медвежье, 2001; Leonova et al., 2007; Belovsky et al., 2011; Оборин и др., 2012; Курочкин и др., 2014 и др.). Основной представитель фауны таких водоемов - жаброногий рачок артемия, приспособившийся к жизни в экстремальных условиях, относится к ценным видам биоресурсов. Цисты этого рачка являются наиболее востребованными для получения стартовых живых кормов для личинок рыб и ракообразных (Чепуркина и др., 2014; Ковачева и др., 2019 и др.).

Согласно официальной статистике, в России ежегодно добывается около 1100 т сырой массы цист, из них в оз. Медвежье в среднем около 140 т, что составляет $2 \%$ от мирового промысла (Litvinenko et al., 2015; Литвиненко и др., 2019).

Организация такого крупномасштабного промысла цист артемии предполагает проведение как комплексных исследований процессов, протекающих в экосистеме озера, так и всесторонней оценки возможных последствий.

Целью исследования было определить степень влияния промысла цист на экосистему гипергалинного озера на примере наиболее изученного оз. Медвежье.

\section{Материал и методы исследований}

Исследования проведены на оз. Медвежье (55²0'с.ш., 6801'в.д.) в 1995-2018 гг. с периодичностью 2-5 экспедиций в год. В 2000-2003 гг. осуществляли круглогодичный мониторинг, при этом частота съемок увеличилась до 7-18 в год. Всего 104 съемки. Видовой и количественный составы фитопланктона были исследованы в 2000-2006 гг. Эксперименты по определению первичной продукции проведены в 2000-2001 гг., результаты которых были опубликованы в печати (Литвиненко и др., 2009). Продукция рачков и цист рассчитана для сезонов 2001-2003 гг.

Озеро Медвежье расположено в ТоболИшимском междуречье, в полосе южной лесостепи степной зоны, лесостепной подзоны. Для местности характерна резкая континентальность с преобладанием испаряемости над поступлением осадков.

Озеро состоит из двух частей: Большое Медвежье площадью 38,3 км² и Малое Медвежье площадью 18,1 км² $^{2}$, соединенных протокой шириной около 100 м и длиной 1 км, которая в засушливые годы пересыхает (рис. 1). Глубина озера в большинстве мест не превышает 1-1,5 м. В наиболее засушливые годы (2010-2012 гг.) средняя глубина озера составляла 0,4-0,5 м. Дно ровное, плоское, покрытое сильноминерализованными среднесульфидными материковыми иловыми грязями, мощностью до 60-70 см (Курочкин и др., 2014). С 1925 г. на озере проводится организованное 


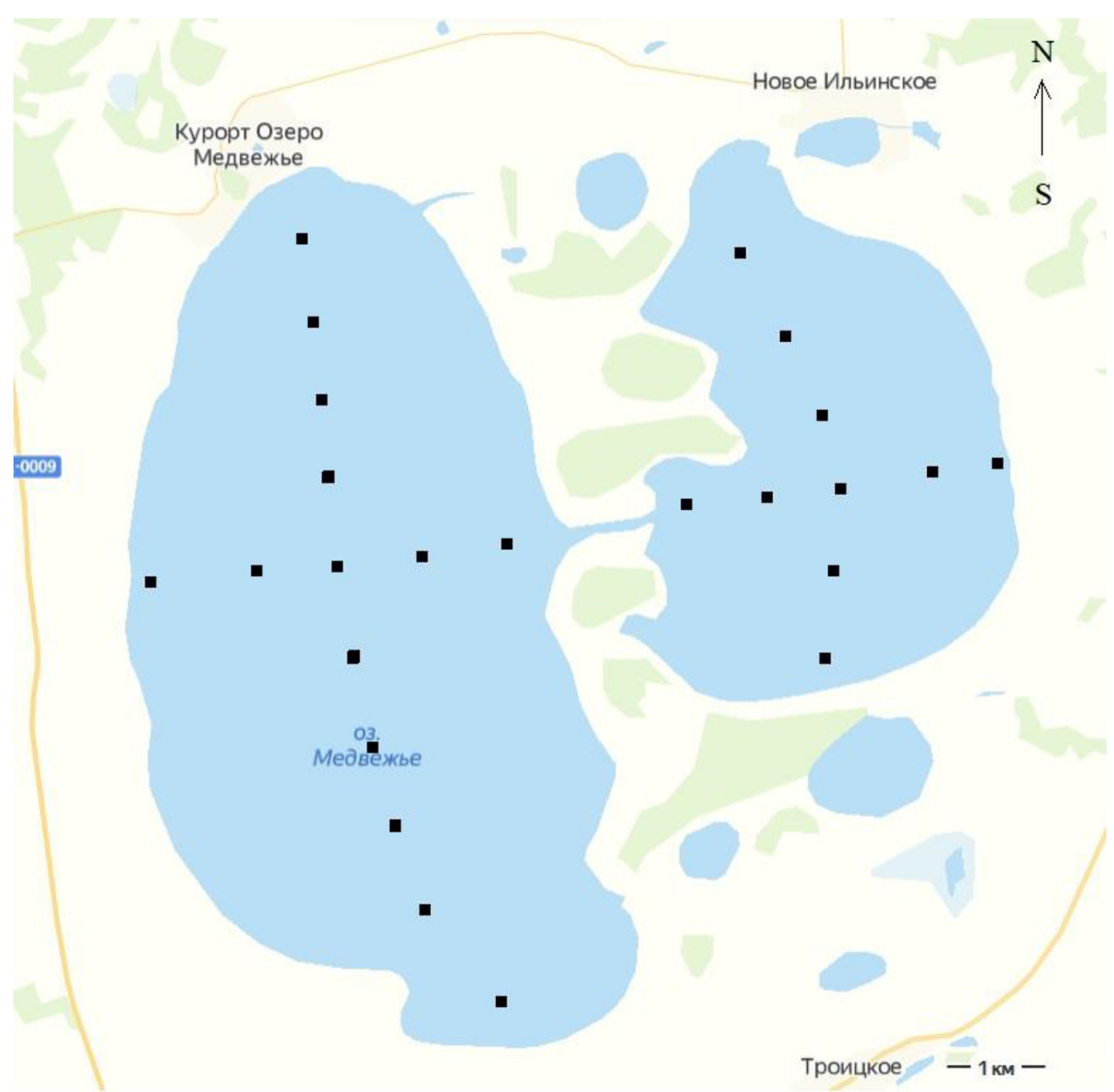

Рис. 1. Озеро Медвежье со станциями отбора проб (Яндекс-карты)

Fig. 1. Medvezhye Lake and the sampling stations (Yandex Maps)

санаторно-курортное лечение, с 2014 г. - добыча лечебных грязей (Озеро Медвежье, 2001; Курочкин и др., 2014).

Мониторинг включал исследования температуры и прозрачности воды, растворенного кислорода, отбор проб воды, фитопланктона, зоопланктона и зообентоса. Пробы на химический анализ воды объемом 1,5 л отбирали с глубины 30 см. Обработка проб проводилась в стационарной аккредитованной лаборатории (аттестат № ROCC RU 0001511311) согласно (Руководство по химическому анализу..., 1977; Алекин и др., 1973). Соленость воды определяли в полевых ус- ловиях при помощи рефрактометра, в лабораторных - по аттестованной методике (РД 52.24.514-2002).

Пробы фитопланктона объемом 1,5-2,0 л концентрировали методом отстаивания до 10 мл. Сбор и обработку проб проводили по общепринятым методикам (Лаврентьева, Бульон, 1981) с использованием микроскопа Микмед-2 (Россия) в камерах Горяева и Фукса-Розенталя.

Интенсивность фотосинтеза фитопланктона изучали с использованием экспозиции кислородных склянок в озере в течение суток (Винберг, 1960; Бульон, 1983). Продукцион- 
ные коэффициенты фитопланктона рассчитаны с учетом того, что эффективная продукция составляет $80 \%$ от валовой, при переводных коэффициентах: 0,3 мгС/мгО ${ }_{2}$ и 3,38 кал/мгО (Винберг, 1970; Бульон, 1983). Калорийность фитопланктона была принята в зависимости от видового состава фитопланктона и находилась в пределах от 0,6 до 1,0 кал/мг. Наименьшую величину калорийности (0,6 кал/мг сырого вещества) использовали в расчетах, если биомасса диатомовых водорослей составляла $100 \%$ общей. Наибольшую калорийность (1 кал/мг сырого вещества) брали при удельной массе диатомовых менее $40 \%$. При 85, 70, $55 \%$ содержания диатомей от общей биомассы калорийность принимали соответственно 0,7, 0,8 и 0,9 кал/мг сырого вещества (Михеева, 1970; Терешенкова, 1983). При расчете годовой продукции фитопланктона были использованы среднесезонные показатели валовой продукции, измеренной скляночным способом.

Отбор проб зоопланктона проводили на 10-18 станциях фильтрованием 50 л воды через планктонную сеть Апштейна (размер ячеи 140 мкм). Пробы фиксировали четырехпроцентным раствором формалина. При камеральной обработке рачков просчитывали в камере Богорова под бинокуляром МБС-10 (Россия), оборудованным окуляр-микрометром, разделяя по возрастным группам: цисты, науплиусы, метанауплиусы, ювенильные, предвзрослые, взрослые особи (самцы, самки с цистами и без цист). Численность цист и науплиусов просчитывали в 5-10 мл пробы в 2-3 повторностях с последующим пересчетом на весь объем пробы. Взрослых особей просчитывали в чашках Петри полностью во всей пробе. Индивидуальную массу взрослых рачков определяли прямым взвешиванием на торсионных весах ВТ-500 (Россия). Данные об индивидуальной массе на- уплиусов взяты из литературных источников (Хмелева, 1968).

Пробы бентоса отбирали при помощи дночерпателя с площадью захвата грунта

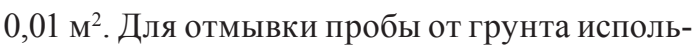
зовали мешок из капронового сита (размер ячеи 160 мкм). Крупные организмы просчитывали и взвешивали по всей пробе. При камеральной обработке объем пробы доводили до 200-500 мл (в зависимости от количества пробы). Численность цист подсчитывали в 2-10 мл в трех повторностях в камере Богорова под бинокуляром МБС-10.

Общие запасы цист артемии определяли по методике, разработанной ФГБНУ «Госрыбцентр» (Литвиненко и др., 2002). В расчет взяты цисты, находящиеся в планктоне, бентосе, овисаках самок и береговых выбросах. Методы расчета подробно представлены в предыдущих публикациях (Van Stappen et al., 2009; Литвиненко и др., 2009; Litvinenko et al., 2015; 2016).

Скорость продукции артемии вычисляли по формуле, первоначально представленной в работе Г.А. Печень (1968) и модернизированной позднее М.Б. Ивановой (1985):

$$
P^{\prime}(t)=\sum_{i=1}^{n}\left(w_{i}-w_{i-1}\right) N_{t} / D_{i}+w_{0} N_{0} / D_{0},
$$

где $w_{0}, w_{i}$ - масса яиц и рачков разных возрастных стадий, мг или кал; $D_{0}, D_{i}$ - продолжительность развития возрастной стадии, сут; $N_{0}, N_{i}$ - численность яиц и рачков разных возрастных стадий, шт/л.

Продукцию за сезон вычисляли по формуле

$$
P=P^{\prime}(t) \cdot t
$$

где $t$ - промежуток времени (сутки, месяц, сезон).

Для расчета были использованы следующие данные: 
$\mathrm{D}_{0}, \mathrm{D}_{1}, \ldots \mathrm{D}_{5}=7$ сут; $w_{0}=0,01 \mathrm{м \Gamma}, w_{1}=0,02 \mathrm{M \Gamma}$, $w_{2}=0,2 \mathrm{мг}, w_{3}=0,6 \mathrm{M \Gamma}, w_{4}=2,0 \mathrm{M \Gamma}, w_{5}=4,0$ мг. Размер кладки 20 яиц. Эти данные взяты из анализа литературных источников (Dutrieu, 1960; Хмелева, 1968; Schrehardt, 1987; Соловов, Студеникина, 1990; Голубев, 2004) и собственных наблюдений. В расчетах было принято, что самки, достигнув взрослой стадии, не увеличивают свою массу.

При расчете продукции артемии были взяты литературные данные (Хмелева, 1968) о том, что в 1 мг сухого вещества содержится 5,2 кал, сырого - 0,518 кал, содержание воды в теле рачков 89 \%. Собственные данные: влажность цист $50 \%$, средняя масса сухих цист 0,005 мг, гидратированных - 0,01 мг, следовательно, калорийность 1 цисты равна 0,026 кал, в 1 мг сухих цист 5,2 кал, сырых цист - 2,6 кал.

Средняя продолжительность сезона развития рачков артемии, на основе собственных мониторинговых данных, принята за 180 сут (в период 15 апреля - 15 октября).
Статистическую обработку данных проводили по Г.Ф. Лакину (1990). При анализе использовали среднюю величину $(M)$, ошибку средней величины $(m)$, величину коэффициента вариации $(C v)$, стандартное отклонение $(S D)$, коэффициент корреляции (r), выборку (n). Расчет всех числовых показателей произведен в программе Microsoft Excel.

\section{Результаты}

Абиотические условия в водоеме

Соленость рапы озера в исследованные годы менялась от 110 до 320 г/дм³ (рис. 2) и зависела от водности года. Основу минерального состава воды составлял хлорид натрия (72-82 \% от суммы ионов). Содержание сульфатов в течение сезона колебалось от 1,7 до $25,5 \%$. Доля их меньше всего в зимнее время $(1,7-8,8 \%)$ за счет осаждения мирабилита и самая высокая в апреле - мае (13,3-25,5 \%). Доля основных ионов рапы в озере по среднемноголетним данным представлена на рис. 3 .

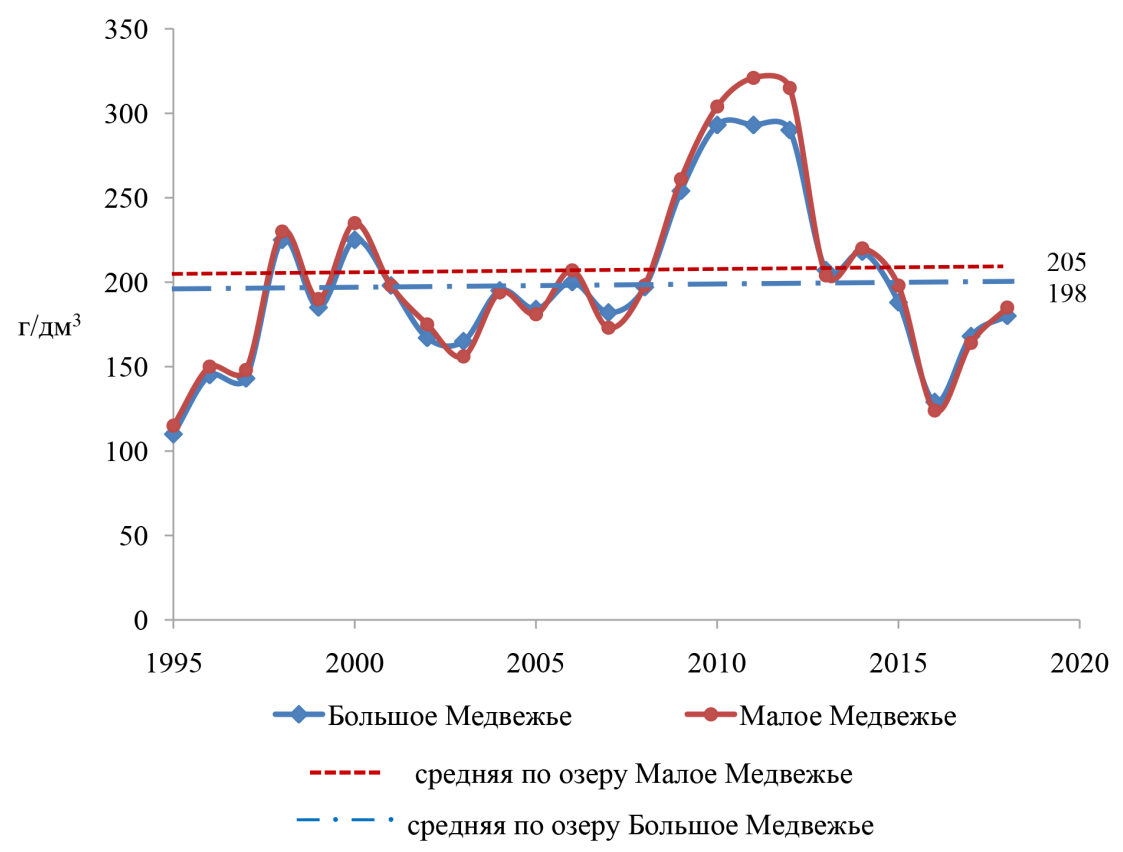

Рис. 2. Многолетняя динамика солености воды в оз. Медвежье

Fig. 2. Long-term dynamics of salinity in Medvezhye Lake

$$
-353-
$$




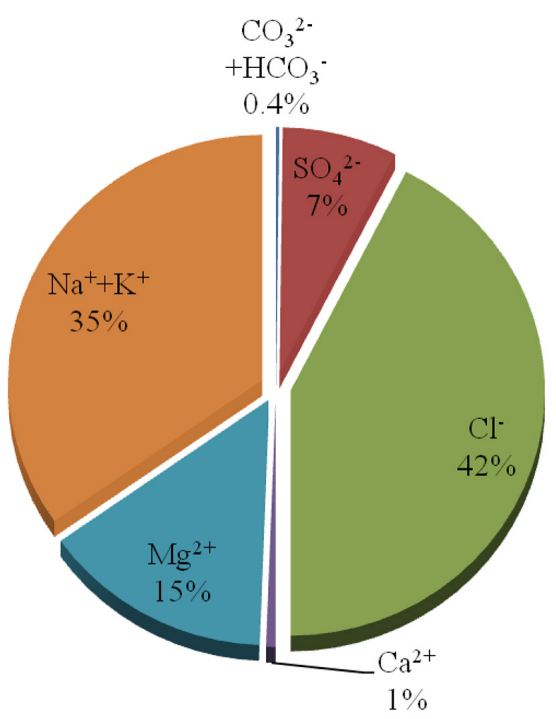

Рис. 3. Химический состав рапы оз. Медвежье

Fig. 3. The chemical composition of the brine of Medvezhye Lake

Среда воды нейтральная и слабощелочная. Перманганатная окисляемость высокая (12,0-92,4 мгО/л). БПК в пределах 1,44,1 мгО $\mathrm{O}_{2}$ /л. Вода жесткая (360-1400 мг-экв/л).

Из-за высокой плотности воды содержание кислорода, как правило, не превышало $6,0 \mathrm{мг} \mathrm{O}_{2} /$ л. При высокой температуре его концентрация опускалась до 0 мг $\mathrm{O}_{2} / л$, что приводило к массовой гибели рачков артемии. В 2000 г. такая ситуация регистрировалась во многих водоемах Курганской области (Озеро Медвежье, 2001).

Благодаря мелководности (среднегодовая глубина в пределах 40-150 см) в озере наблюдается гомотермия. В годовой динамике температуры были выявлены следующие закономерности:

- в течение года амплитуда колебаний температуры составляла $43-48^{\circ} \mathrm{C}$;

- максимальная летняя температура 36-38 ${ }^{\circ} \mathrm{C}$, минимальная, равная минус $13{ }^{\circ} \mathrm{C}$, а по литературным данным, и до минус $19{ }^{\circ} \mathrm{C}$ (Озеро Медвежье, 2001) наблюдалась в январе - феврале;
- прогрев рапы до $5{ }^{\circ} \mathrm{C}$ и выше (сопровождаемый вылуплением науплиусов из перезимовавших цист) зафиксирован в середине апреля, снижение температуры воды до $5{ }^{\circ} \mathrm{C}$ и ниже (сопровождаемое гибелью рачков) наблюдалось в конце сентября - октябре;

- температура воды в летний период в основном в пределах оптимума для рачков артемии $\left(20-26^{\circ} \mathrm{C}\right)$.

Прозрачность воды в тихую солнечную погоду, как правило, до дна. При волнении, из-за взмучивания донных (грязевых) отложений, менее $30 \mathrm{~cm}$.

Образование льда на озере наблюдалось в конце декабря. Лед рыхлый. При высокой солености (более 300 г/дм³) лед не образовывался. В зимний период лед отсутствовал также на соленых озерах Крыма (Golubkov, 2012), что объясняется изменением температуры замерзания в соленых водах: при концентрации солей $>50 \%$ температура замерзания минус $3{ }^{\circ} \mathrm{C}$, при $100 \%$ - минус $7{ }^{\circ} \mathrm{C}$, при $250 \%$ снижается до минус $20{ }^{\circ} \mathrm{C}$ (Prokopiev et al., 2010). 


\section{Фитопланктон}

За весь период исследований в составе фитопланктона озера было выявлено 14 видов и разновидностей, относящихся к трем отделам водорослей. Зеленые были представлены пятью таксонами: Dunaliella salina Teod., Dunaliella viridis Teod., Pedinomonas tenuis Masiuk, Coelastrum astroideum DeNotaris, Chlorella vulgaris Beijer., диатомовые - четырьмя таксонами: Melosira varians Ag., Amphora coffeaeformis var. transcaspica Boye P., Nitzschia angustata (W.Sm.) Grun., Nitzschia punctata var. minutissima Por., цианобактерии - пятью таксонами: Lingbya limnetica Lemm., Oscillatoria chlorina (Kutz.) Gom., Oscillatoria limosa Ag., Oscillatoria agardhii f. aequicrassa Elenk., Synechococcus elongatus Nag. К доминирующим видам относились D. salina, D. viridis, $N$. angustata, L. limnetica .

Индекс видового разнообразия очень низок и находится в пределах 1,07-1,83 бит/мг. В экологическом отношении фитопланктон представлен в основном солоноватоводным комплексом широко распространенных, ис- тинно- и факультативно-планктонных видов, относящихся к $\beta$-мезосапробам.

В количественном отношении в фитопланктоне преобладают зеленые (в частности, вольвоксовые) и диатомовые водоросли, на третьем месте - цианобактерии (рис. 4).

Фитопланктон озера характеризуется незначительной биомассой, но очень высокими продукционными характеристиками. Так, биомасса в отдельные даты в период 20002006 гг. колебалась в пределах 0,01-8,6 мг/л и составляла в среднем $0,75 \pm 0,11$ мг/л $(n=49)$, или 7,5 кг/га. Причем функционирование фитопланктона происходило круглый год, и даже в зимние месяцы биомасса фитопланктона была соизмерима с летними показателями (рис. 5). Так, биомасса фитопланктона в мае-сентябре, в период развития в биоценозе рачков артемии, была в пределах 0,01-8,6 мг/л $(0,77 \pm 0,18 \mathrm{мг} / л, n=30)$; а в октябре-апреле, при отсутствии активных фильтраторов, составляла 0,01-7,7 мг/л $(0,74 \pm 0,13$ мг/л, $n=19)$.

Относительно низкая биомасса фитопланктона в летний период объясняется тем, что фитопланктон в это время находится под

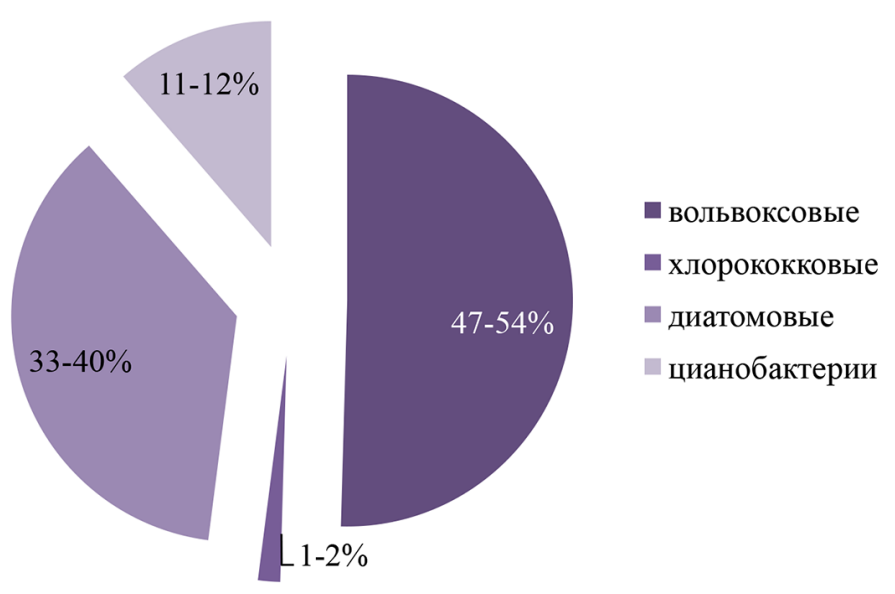

Рис. 4. Доля различных групп водорослей в общей биомассе фитопланктона оз. Медвежье (по многолетним данным)

Fig. 4. Proportions of different groups of algae in the total phytoplankton biomass of Medvezhye Lake (long-term data) 


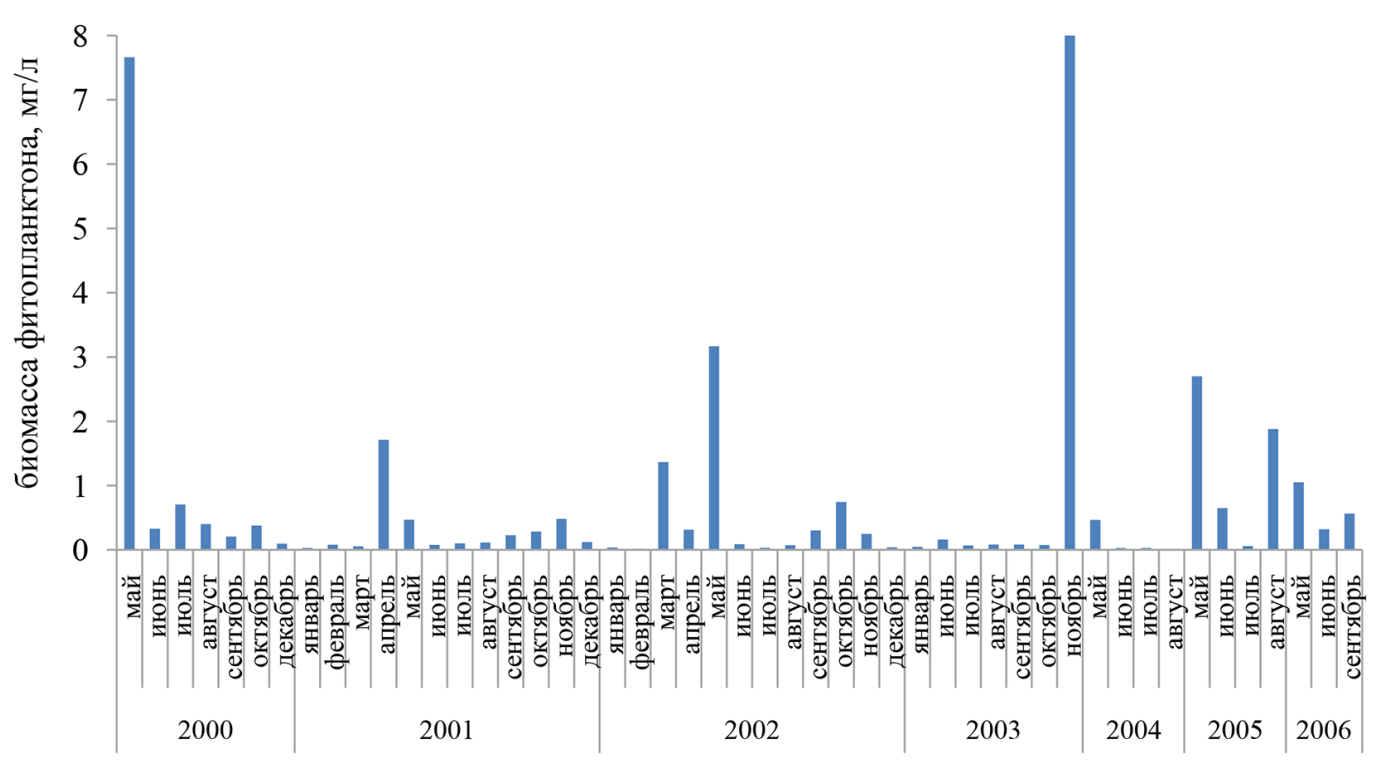

месяц и год исследования

Рис. 5. Динамика среднемесячной биомассы фитопланктона в оз. Медвежье в 2000-2006 гг.

Fig. 5. Dynamics of monthly average phytoplankton biomass in Medvezhye Lake in 2000-2006

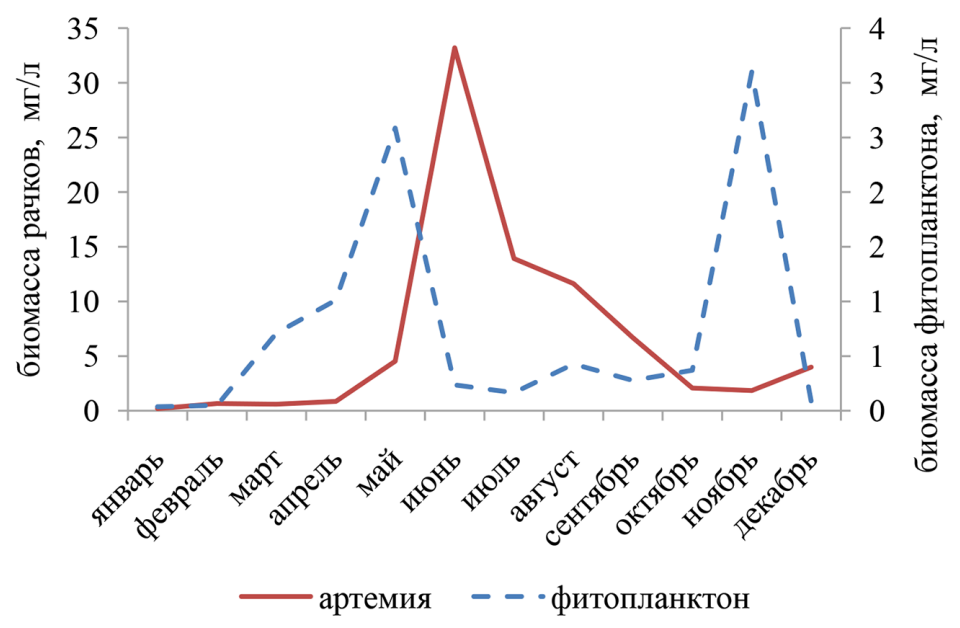

Рис. 6. Годовая динамика фитопланктона и рачков артемии (по усредненным данным по биомассе за 2000-2006 гг.)

Fig. 6. Annual dynamics of phytoplankton and Artemia shrimp (based on average biomass data for 2000-2006)

сильным прессом таких мощных фильтраторов, как артемия. При отмирании рачков осенью и в начале их развития весной наблюдаются вспышки в развитии фитопланктона (рис. 6). Между биомассой фитопланктона и биомассой рачков артемии установлена слабая отрицательная связь $(r=-0,17, n=43)$.

Величина суточной валовой первичной продукции фитопланктона в озере различалась значительно, от 0,01 до 3,6 мгО $2 /$, 
и в среднем составила около 1,0 мгО $2 /$, или 0,3 гС/м² (табл. 1).
Анализ функционирования фитопланктона по величине удельного фотосинтеза

Таблица 1. Показатели продуцирования фитопланктона в оз. Медвежье

Table 1. Indicators of phytoplankton production in Medvezhye Lake

\begin{tabular}{|c|c|c|c|c|c|c|c|c|c|}
\hline Дата & № станции & $B$ & $V$ & $A$ & $R$ & $A / R$ & $A / B$ & $P / B$ & $\Sigma \mathrm{u}$ \\
\hline 1 & 2 & 3 & 4 & 5 & 6 & 7 & 8 & 9 & 10 \\
\hline \multirow{4}{*}{23.05 .2000} & 1 & 3,82 & 225 & 0,71 & 2,07 & 0,34 & 0,19 & 0,50 & 196 \\
\hline & 3 & 16,58 & 443 & 0,58 & 0,33 & 1,76 & 0,03 & 0,09 & 196 \\
\hline & 4 & 9,46 & 230 & 1,45 & 1,40 & 1,04 & 0,15 & 0,41 & 169 \\
\hline & 5 & 11,98 & 319 & 1,24 & 1,24 & 1,00 & 0,10 & 0,28 & 169 \\
\hline 23.06 .2000 & 1 & 0,22 & 335 & 0,01 & 0,30 & 0,03 & 0,05 & 0,14 & 237 \\
\hline \multirow{4}{*}{06.07 .2000} & 1 & 0,68 & 197 & 2,80 & 1,84 & 1,52 & 4,12 & 11,15 & 243 \\
\hline & 2 & 0,53 & 246 & 2,04 & 0,72 & 2,83 & 3,84 & 10,39 & 243 \\
\hline & 4 & 0,88 & 249 & 0,32 & 2,88 & 0,11 & 0,36 & 0,99 & 246 \\
\hline & 5 & 1,25 & 341 & 3,60 & 2,40 & 1,50 & 2,89 & 7,82 & 246 \\
\hline \multirow{4}{*}{ 21.07.2000 } & 1 & 0,36 & 175 & 0,90 & 0,80 & 1,13 & 2,47 & 6,69 & 225 \\
\hline & 2 & 0,75 & 172 & 2,60 & 1,10 & 2,36 & 3,48 & 9,40 & 225 \\
\hline & 4 & 0,87 & 189 & 2,50 & 1,60 & 1,56 & 2,88 & 7,80 & 225 \\
\hline & 5 & 0,59 & 209 & 3,01 & 1,11 & 2,71 & 5,12 & 13,84 & 225 \\
\hline \multirow{4}{*}{10.08 .2000} & 1 & 0,11 & 225 & 0,31 & 1,10 & 0,28 & 2,74 & 9,27 & 199 \\
\hline & 2 & 0,03 & 175 & 0,06 & 1,02 & 0,06 & 1,82 & 5,46 & 199 \\
\hline & 4 & 0,55 & 265 & 3,21 & 2,01 & 1,60 & 5,79 & 15,67 & 215 \\
\hline & 5 & 0,50 & 295 & 2,50 & 1,50 & 1,67 & 4,96 & 13,41 & 215 \\
\hline \multirow{4}{*}{05.09 .2000} & 1 & 0,15 & 182 & 0,28 & 0,17 & 1,65 & 1,92 & 5,19 & 231 \\
\hline & 2 & 0,22 & 213 & 1,81 & 0,90 & 2,01 & 8,38 & 22,66 & 231 \\
\hline & 4 & 0,13 & 209 & 0,33 & 1,64 & 0,20 & 2,54 & 6,86 & 255 \\
\hline & 5 & 0,31 & 368 & 1,04 & 1,71 & 0,61 & 3,31 & 8,96 & 255 \\
\hline \multirow{4}{*}{21.09 .2000} & 1 & 0,58 & 617 & 0,16 & 1,92 & 0,08 & 0,28 & 0,75 & 245 \\
\hline & 2 & 0,27 & 223 & 0,08 & 2,21 & 0,04 & 0,30 & 0,80 & 245 \\
\hline & 4 & 0,24 & 304 & 0,24 & 1,60 & 0,15 & 1,01 & 2,73 & 247 \\
\hline & 5 & 0,56 & 439 & 0,26 & 1,43 & 0,18 & 0,47 & 1,26 & 247 \\
\hline 21.06 .2001 & 5 & 0,09 & 94 & 1,12 & 1,92 & 0,58 & 12,58 & 7,81 & 197 \\
\hline \multirow{2}{*}{ 11.07.2001 } & 4 & 0,03 & 98 & 0,10 & 2,60 & 0,04 & 2,94 & 7,95 & 199 \\
\hline & 5 & 0,05 & 74 & 0,01 & 1,00 & 0,01 & 0,20 & 0,53 & 199 \\
\hline \multirow{4}{*}{ 04.08.2001 } & 1 & 0,28 & 118 & 1,00 & 2,50 & 0,40 & 3,55 & 11,99 & 220 \\
\hline & 2 & 0,10 & 68 & 0,30 & 2,30 & 0,13 & 2,94 & 9,94 & 220 \\
\hline & 4 & 0,02 & 41 & 0,08 & 1,40 & 0,57 & 4,71 & 12,72 & 210 \\
\hline & 5 & 0,06 & 94 & 0,14 & 4,30 & 0,03 & 2,37 & 6,42 & 210 \\
\hline \multirow{2}{*}{23.08 .2001} & 1 & 0,03 & 78 & 0,14 & 2,24 & 0,64 & 5,33 & 14,42 & 230 \\
\hline & 4 & 0,01 & 333 & 0,01 & 0,56 & 0,02 & 1,11 & 5,01 & 236 \\
\hline
\end{tabular}


Продолжение табл. 1

Continuation Table 1

\begin{tabular}{|c|c|c|c|c|c|c|c|c|c|}
\hline 1 & 2 & 3 & 4 & 5 & 6 & 7 & 8 & 9 & 10 \\
\hline $\min$ & & 0,01 & 41 & 0,01 & 0,17 & 0,01 & 0,03 & 0,09 & 169 \\
$\max$ & & 16,58 & 617 & 3,60 & 4,30 & 2,83 & 12,58 & 22,66 & 255 \\
$\mathrm{M}$ & & 1,54 & 230,7 & 1,03 & 1,58 & 0,85 & 2,79 & 7,04 & 222 \\
$\mathrm{~m}$ & & 0,63 & 21,18 & 0,19 & 0,14 & 0,15 & 0,46 & 0,95 & 3,93 \\
$\mathrm{Cv}$ & & 239 & 54 & 107 & 53 & 100 & 96 & 79 & 10 \\
$\mathrm{SD}$ & & 3,69 & 123,51 & 1,10 & 0,84 & 0,85 & 2,67 & 5,55 & 22,90 \\
$\mathrm{n}$ & & 34 & 34 & 34 & 34 & 34 & 34 & 34 & 34 \\
\hline
\end{tabular}

Примечание: $B$ - биомасса фитопланктона, мг/л, $V$ - объем клеток водорослей, мкм ${ }^{3}, A$ - валовая продукция, мгО $/$ л, $R$ - деструкция, мг $\mathrm{O}_{2} /$ л, $A / B$ и $P / B$ - суточные коэффициенты, $\Sigma \mathrm{u}-$ соленость воды, г/л.

$(A / B)$ показал, что альгоценоз озера ввиду его мелкоклеточности (в среднем $231 \pm 21$ мкм $^{3}$ ), определенного видового состава (особенно наличия вольвоксовых), а также, вероятно, по причине некоторых физиологических особенностей является весьма высокопродуктивным. Так, суточные значения $A / B$ коэффициента фитопланктона озера находились в пределах 0,03-12,58 и в среднем были равны 2,8. При максимальных значениях $A / B$-коэффициентов в планктоне преобладали наннопланктонные формы из вольвоксовых и цианобактерий.

С учетом круглогодичного функционирования фитопланктона в озере его годовая продукция составила 88 гС/ $\mathrm{M}^{2}$, или 987 ккал/м², что соответствует 8390 кг/га. Этот показатель по шкале трофности соответствует эвтрофному типу озер.

\section{Зоопланктон}

Зоопланктон озера очень беден, за весь период исследований было обнаружено только пять видов, принадлежащих в систематическом отношении к двум типам: членистоногие (Arthropoda) и круглые черви (Nematoda). Из членистоногих - два представителя ракообразных (жаброноги - рода Artemia Leach, 1819, веслоногие - Cletocamptus retrogressus
Schm., 1875) и два вида личинок насекомых (Ephydrae и Chironomidae). Из круглых червей был встречен один вид нематод.

Биомасса зоопланктона (без артемии) находилась в пределах 0-1,5 мг/л (в среднем $0,08 \pm 0,02$ мг/л, $n=195)$, в пересчете на гектар площади 0,8 кг/га, биомасса рачков артемии - в пределах 0-359,4 мг/л (в среднем $21,9 \pm 3,2$ мг/л, $n=195)$ или 219 кг/га.

Продукция артемии, рассчитанная в озере в течение трех сезонов (2001-2003 гг.), была в пределах 130-451 ккал/м² и в среднем составила 315 ккал/м² (2678 кг/га·год) (табл. 2), или

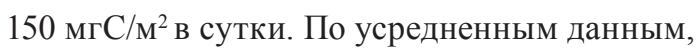
сезонный $P / B$-коэффициент равен $12,6 \pm 2,4$, суточный $-0,07$.

Доля суточной продукции артемии от эффективной (чистой) первичной продукции фитопланктона составила $62,5 \%$.

В планктоне помимо рачков артемии были встречены их цисты в количестве от 0 до 6757 экз/л (в среднем $-237,9 \pm 43,6, n=195)$, в пересчете на биомассу - 2,4 мг/л, или 24 кг/га.

\section{Бентос}

Фитобентос в озере отсутствовал. Зообентос представлен личинками мухи-береговушки семейства Ephydridae и цистами артемии. Личинки рода Ephydra Fallen, 
Таблица 2. Среднесезонные значения продукции, биомассы рачков и цист в оз. Медвежье

Table 2. Mean seasonal values of Artemia production, cyst and shrimp biomass in Medvezhye Lake

\begin{tabular}{|c|c|c|c|c|c|}
\hline \multirow[t]{2}{*}{ Год } & \multirow{2}{*}{$\begin{array}{c}\text { Соленость, } \\
\text { г/дм }{ }^{3}\end{array}$} & \multirow{2}{*}{$\begin{array}{c}\text { Продукция } \\
\text { за сезон, ккал/м² }\end{array}$} & \multicolumn{2}{|c|}{$\begin{array}{c}\text { Среднесезонная биомасса, } \\
\text { ккал/м }{ }^{2}\end{array}$} & \multirow[t]{2}{*}{$\mathrm{P} / \mathrm{B}$ за сезон } \\
\hline & & & рачков & цист & \\
\hline 2001 & 198 & 364,0 & 9,7 & 12,6 & 16,3 \\
\hline 2002 & 167 & 451,0 & 16,5 & 22,4 & 11,6 \\
\hline 2003 & 165 & 130,0 & 5,2 & 8,1 & 9,8 \\
\hline $\mathrm{M}$ & & 315,0 & 10,5 & 14,4 & 12,6 \\
\hline $\mathrm{SD}$ & & 166,0 & 5,7 & 7,3 & 3,4 \\
\hline $\mathrm{Cv}$ & & 52,7 & 54,4 & 50,9 & 26,7 \\
\hline $\mathrm{m}$ & & 117,4 & 4,0 & 5,2 & 2,4 \\
\hline
\end{tabular}

1810 наблюдались в каждой третьей пробе в количестве от 10 до 200 экз/ $\mathrm{M}^{2}$ (в среднем 17,5 экз/м²), при этом биомасса их была незначительной - около 0,12 г/м² $(1,2$ кг/га).

Донные цисты артемии встречались в озере почти круглый год, их отсутствие было отмечено лишь в отдельных пробах в зимние и весенние месяцы.

Средняя по станциям численность цист была в пределах от 0 до 18,6 млн экз/ м $^{2}$, биомасса колебалась от 0 до 186 г/м² , составляя в среднем 109,6 кг/га.

\section{Продукция цฺист}

Ежегодная продукция цист за 24 года исследований (рис. 7) была в пределах от 42 кг/га (1999 г.) до 303 кг/га (2002 г.), т.е. различалась в 7 раз. В период 1995-2018 гг. запасы цист в озере составили в среднем 114,5 $\pm 14,3$ кг/га $(C v=58 \%)$. Средняя продукция за весь период, более 100 кг/га в год, согласно принятой градации (Методические рекомендации..., 2019) характеризует этот водоем как высокопродуктивный.

\section{Промысел цист}

Официальный промысел цист артемии ведется на озере Медвежье с 1995 г. До этого периода он был незначительным ввиду отсутствия источника сбыта. В 1995-2018 гг. вылов составил $23,7 \pm 5,8$ кг/га $(C v=60 \%)$.

Анализ возможности влияния промысла на экосистему озера

Каждый год в озере заготавливали в среднем $20 \%$ цист от годовой продукции. Таким образом, значительная часть цист (около 90 кг/га) при такой интенсивности промысла остается в озере и служит источником пополнения численности 1-й генерации рачков в весенний период.

Согласно представленным материалам, в целом по оз. Медвежье главные составляющие экосистемы озера продукция фитопланктона - продукция артемии - продукция цист артемии находятся в следующем соотношении $-8390: 2678: 115$ кг/га·год. При переводе в процентное соотношение эта пропорция будет выглядеть следующим образом: $75: 24$ : $1 \%$. Изъятие цист артемии из озера в количестве 24 кг/га составляет лишь 0,22 \% от продукции всех рассмотренных компонентов, что ничтожно мало по сравнению с остальными компонентами биоценоза и по этой причине не могло оказывать существенное влияние на экосистему озера. 


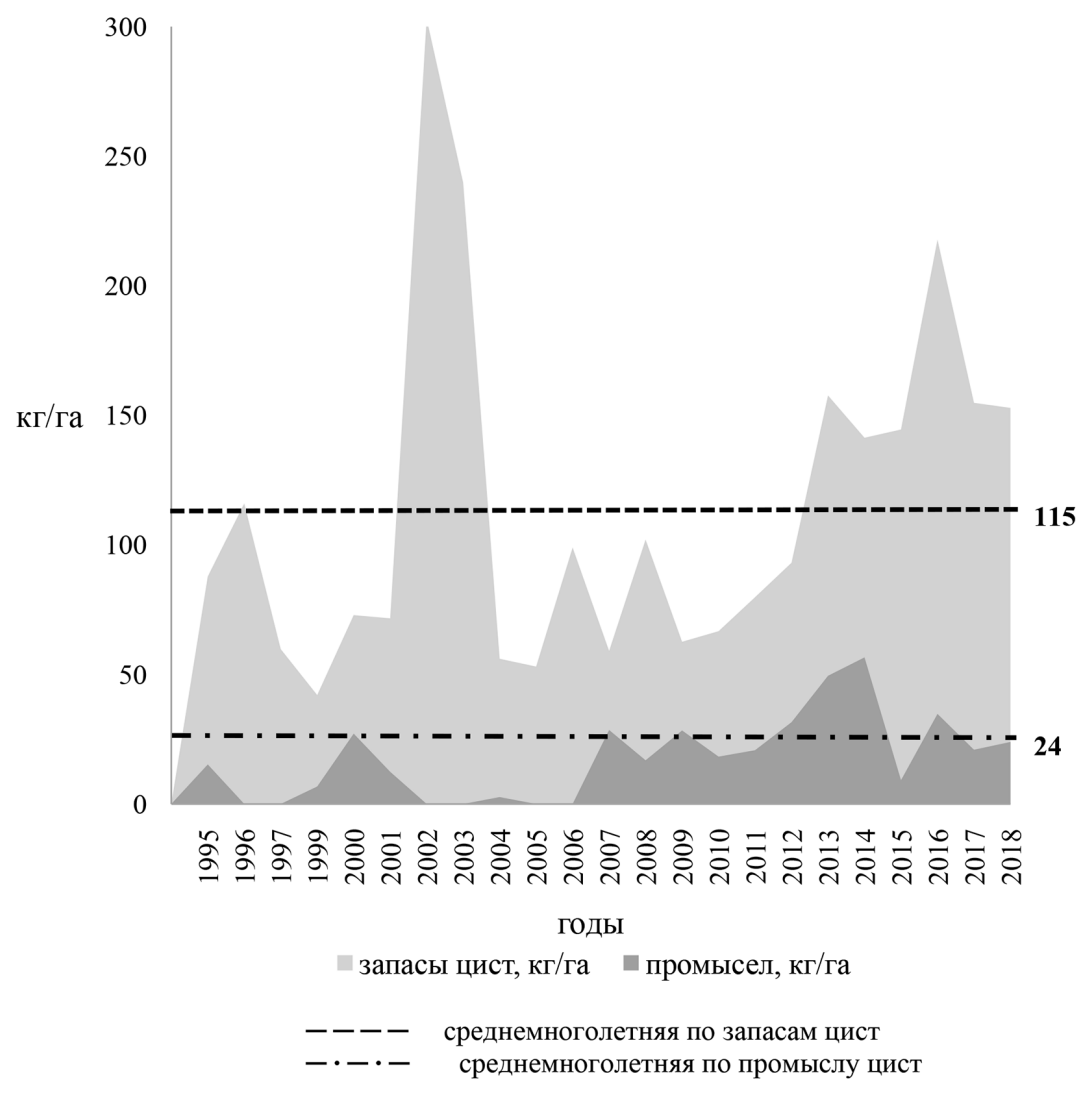

Рис. 7. Многолетняя динамика запасов и промысла цист артемии в оз. Медвежье

Fig. 7. Long-term dynamics of stocks and harvesting of Artemia cysts in Medvezhye Lake

\section{Обсуждение}

В России более 100 артемиевых озер и только половина из них охвачена промыслом цист, поскольку продуктивность их зависит от солености воды, которая в мелководных озерах значительно колеблется как в течение сезона, так и в межгодовом аспекте. Согласно литературным (Post, Youssef, 1977; De Los Santos et al., 1979; Богатова, 1980; Vanhaecke et al., 1984; Sorgeloos et al., 1986; Bhargava et al., 1987; Wear, Haslett, 1987; Tackaert, Sorgeloos, 1991; Van Stappen et al., 2009; Shadrin, Anufrieva, 2012; Shadrin et al., 2012; 2019) и собственным данным, граница встречаемости рачков находится в пределах солености 30-400 г/л. При солености 70-230 г/л артемия развивается нормально. Соленость в пределах
70-150 г/л оптимальна для продукции рачков, 110-200 г/л - для продукции цист. При солености 30-50 и 250-400 г/л рачки встречаются единично.

В оз. Медвежье соленость в разные годы колебалась в пределах от 110 до 330 г/л, в среднем за весь период исследования около 200 г/л, т.е. была в пределах оптимума для производства цист артемии. Озеро Медвежье можно отнести к типичным промысловым артемиевым водоемам, поэтому полученные нами выводы о влиянии промысла цист на экосистему гипергалинного мелководного водоема являются общими для подобных озер.

Высокая соленость воды гипергалинных водоемов способствует снижению биоразнообразия как фауны, так и флоры, об этом 
свидетельствует малое количество видов фитопланктона, зоопланктона и зообентоса в оз. Медвежье. Кроме этого, такая соленость приводила к предельному упрощению трофической планктонной цепи, по сути, до «монокультуры» артемии. В оз. Медвежье не было обнаружено представителей фитобентоса. Объяснение этому дано в работе Е.В. Балушкиной с соавторами (2009), которые, исследуя водоемы Крыма, показали, что при солености 100 \%о первичные продуценты представлены в основном донными макроводорослями, при дальнейшем повышении солености (до 120 \% и более) происходит редукция бентосной трофической цепи и упрощение планктонной. С увеличением солености до 184-340 \%о первичные продуценты представлены исключительно водорослями планктона, трофическая планктонная цепь предельно упрощается, в озерах обитает лишь артемия. При этом в отсутствие пресса хищников и пищевых конкурентов эффективность утилизации энергии первичных продуцентов артемией резко возрастает.

Средние значения годовой первичной продукции, полученные в оз. Медвежье, равные 88 гС/ $\mathrm{M}^{2}$, очень близки к годовой первичной продукции, рассчитанной В.В. Бульоном с соавторами (1989) для озер Крыма (25-110 гС/ $\left.{ }^{2}\right)$, что служит свидетельством схожести продуктивности сибирских озер, несмотря на их более северное положение, с южными озерами Крыма.

Функционированию фитопланктона в зимнее время в оз. Медвежье способствуют как световые условия (рыхлый тонкий лед либо его отсутствие при высокой солености), видовой состав (диатомовые), так и отсутствие в биоценозе потребителей. Круглогодичное функционирование фитопланктона в оз. Медвежье, показанное нами, также характерно для соленых водоемов Крыма. Так, в работе (Golubkov, 2012) было отмечено, что в оз. Кояшское именно в зимний период из-за отсутствия непосредственных потребителей фитопланктона в процессе фотосинтеза происходит накопление органических веществ, которые в последующем либо накапливаются в донных отложениях, либо используются биотой в следующий летний сезон.

Значения продукции артемии, рассчитанные в оз. Медвежье по трем сезонам (1105-3834 кг/га·год), были несколько ниже значений продуктивности расположенных южнее пяти мелководных гипергалинных водоемов Северо-Восточного Казахстана: 134-11745 кг/га, в среднем 4142 кг/га (Матмуратов и др., 2004), и соответствовали нижней границе продуктивности глубоководного o3. Great Salt Lake (США, штат Юта), расположенного на широте $41^{\circ} 00 ' \mathrm{~N}$, годовая продукция артемии в котором оценивалась в пределах от 100 до 200 г/м² сухой массы (Lenz, 1987) или в переводе на сырую около 3000-8000 кг/га.

В связи с упрощенной трофической системой гипергалинного водоема основным консументом произведенной в озере первичной продукции можно считать артемию. В оз. Медвежье доля продукции артемии от чистой первичной продукции фитопланктона составила 62,5 \%. Подобные высокие результаты (54-68 \%) были получены для оз. Кояшское (Балушкина и др., 2009; Балушкина, 2016) при солености близкой солености о3. Медвежье. Эти результаты свидетельствуют, скорее всего, о неучтенных в данных исследованиях некоторых кормовых ресурсах. Во-первых, это растворенное органическое вещество (РОВ), которое, по литературным данным (Romankevich, Vetrov, 2013), превышает в среднем по соленым водоемам мира взвешенное органическое вещество ВОВ в 2,3 раза. Во-вторых, не учтена продукция 
галофильных бактерий, которая, судя по публикациям (Лаптева, Соколова, 2013), может составлять до $50 \%$ от первичной продукции.

Установленная в этом исследовании величина изъятия цист артемии из озера в количестве 24 кг/га, составляющая 0,22 \% от биомассы всех рассмотренных компонентов, по сути, еще меньше, если учесть РОВ и продукцию микроорганизмов. Исходя из этого, можно заключить, что при существующих технологиях промысла цист артемии в мелководных водоемах вмешательство в экосистему гипергалинного водоема ничтожно мало.

В предыдущих публикациях (Литвиненко и др., 2009) нами были показаны некоторые закономерности годовой динамики цист и их продуцирования в целом, а именно то, что мощность 1-й генерации не оказывает существенного влияния на численность рачков 3-й генерации, продуцирующей промысловые запасы цист. Наоборот, из-за высокой плотности рачков 1-й генерации подрывается кормовая база для последующих поколений.

Многочисленные данные зарубежных ученых (Sorgeloos et al., 1986; Great Salt Lake, 2002; Belovsky et al., 2011; UT-DWR, 2014 и др.) показали, что оптимальная плотность для первой генерации артемии составляет 5-20 науплиусов/л. Наши исследования (Литвиненко и др., 2009; Litvinenko et al., 2016), результаты которых отражены в новой методике определения запасов цист (Методические рекомендации..., 2019), демонстрируют, что для мелководных водоемов необходимая плотность цист для воспроизводства популяции на следующий сезон, т.е. в период 1-й генерации, составляет 10 кг/га, что соответствует плотности 100 цист/л (25 науплиусов/л с учетом вылупляемости цист в весеннее время). Согласно полученным нами усред- ненным данным, в биоценозе оз. Медвежье после промысла остается около 90 кг/га цист, т.е. почти в 9 раз больше указанной плотности. При такой остаточной биомассе цист с учетом процентов их вылупления в весеннее время численность науплиусов 1-й генерации в среднем равна 225 экз/л. Исходя из литературных данных по выживаемости рачков 1-й генерации (Литвиненко и др., 2009) было установлено, что при плотности науплиусов 1000-6000, 100-1000 и <100 экз/л выживаемость соответственно равна $2,4 \pm 0,8,13,9 \pm 4,4$ и $30,8 \pm 10,3 \%$. Таким образом, остаточная после промысла плотность цист выше оптимальной в несколько раз, при этом выживаемость вылупившихся науплиусов низкая. Увеличение интенсивности промысла могло бы повысить выживаемость рачков и в конечном итоге увеличить продукцию цист в водоеме. При данном уровне промысла его роль в экосистеме озера незначительна.

\section{Заключение}

Продукция главных составляющих экосистемы гипергалинного оз. Медвежье фитопланктон - рачки артемии - цисты артемии находится в следующем соотношении - 8390 : $2678: 115$ кг/га·год (75:24:1\%). Изъятие цист артемии из оз. Медвежье в количестве 24 кг/га, составляющее $0,22 \%$ от продукции изученных компонентов биоценоза, не может значительно влиять на экосистему озера. При существующих технологиях из озера изымается только 15 \% от общих запасов цист. Остаточная после промысла численность цист является в большинстве случаев избыточной для формирования численности 1-й генерации артемии. Увеличение интенсивности промысла цист артемии позволит снизить численность рачков 1-й генерации, увеличить их выживаемость и сохранить кормовую базу для последующих генераций. 


\section{Благодарности / Acknowledgements}

Выражаем искреннюю благодарность сотрудникам Тюменского филиала ФГБНУ «ВНИPO» («Госрыбцентр») А.И. Коваленко за проведение гидрохимических анализов и М.А. Ядуванкиной за помощь в обработке проб фитопланктона за 2004-2006 гг.

We express our sincere gratitude to the employees of the Tyumen branch of FSUE "VNIRO" (“Gosrybtsentr") A.I. Kovalenko for conducting hydrochemical analyses and M.A. Yaduvankina for her assistance in processing phytoplankton samples of 2004-2006.

\section{Список литературы / References}

Алекин О.А., Семенов А.Д., Скопинцев Б.А. (1973) Руководство по химическому анализу вод суши. Л., Гидрометеоиздат, 271 с. [Alekin O.A., Semenov A.D., Skopintsev B.A. (1973) Guide to chemical analysis of land waters. Leningrad, Gidrometeoizdat, 271 p. (in Russian)]

Балушкина Е.В., Голубков С.М., Голубков М.С., Литвинчук Л.Ф., Шадрин Н.В. (2009) Влияние абиотических и биотических факторов на структурно-функциональную организацию экосистем соленых озер Крыма. Журнал общей биологии, 70(6): 504-514 [Balushkina E.V., Golubkov S.M., Golubkov M.S., Litvinchuk L.F., Shadrin N.V. (2009) Effect of abiotic and biotic factors on the structural and functional organization of the saline lake ecosystems. Journal of General Biology [Zhurnal obshchei biologii], 70(6): 504-514 (in Russian)]

Балушкина Е.В. (2016) Оценка качества воды и состояния водоемов разного типа по характеристикам сообществ донных животных. Труды Зоологического института РАН, 320(3): 262279 [Balushkina E.V. (2016) Assessment of water quality and state of waterbasins of different types from characteristics of benthic animal communities. Proceedings of the Zoological Institute RAS [Trudy Zoologicheskogo instituta RAN], 320(3): 262-279 (in Russian)]

Богатова И.Б. (1980) Рыбоводная гидробиология. М., Пищевая промышленность, 168 с. [Bogatova I.B. (1980) Fish Culture Hydrobiology. Moscow, Pishchevaya promyshlennost', 168 p. (in Russian)]

Бульон В.В. (1983) Первичная продукиия планктона внутренних водоемов. Л., Наука, 150 с. [Bul'on V.V. (1983) Primary production of plankton of internal waterbodies. Leningrad, Nauka, 150 p. (in Russian)]

Бульон В.В., Анохина Л.Е., Аракелова Е.С. (1989) Первичная продукция гипергалинных озер Крыма. Труды Зоологического института АН СССР, 205: 14-25 [Bul'on V.V., Anokhina L.E., Arakelova E.S. (1989) Primary production of hypersaline lakes in Crimea. Proceedings of the Zoological Institute of the USSR Academy of Sciences [Trudy Zoologicheskogo instituta AN SSSR], 205: 14-25 (in Russian)]

Винберг Г.Г. (1960) Первичная продукиия водоемов. Минск, АН БССР, 329 с. [Vinberg G.G. (1960) Primary production of waterbodies. Minsk, Byelorussian Academy of Sciences, 329 p. (in Russian)]

Винберг Г.Г. (1970) Общие особенности экологической системы оз. Дривяты. Биологическая продуктивность эвтрофного озера. М., Наука, с. 185-196 [Vinberg G.G. (1970) General features of the ecological system of Drivyaty Lake. Biological productivity of the eutrophic lake. Moscow, Nauka, p. 185-196 (in Russian)]

Голубев А.П. (2004) Изменчивость количественных параметров роста и воспроизводства у Artemia (Crustacea, Anostraca) как фактор адаптации к условиям среды и механизм преобра-

$$
-363-
$$


зования жизненных циклов. Биоразнообразие артемии в странах СНГ: современное состояние ее запасов и их использование. Тюмень, СибрыбНИИпроект, с. 105-115 [Golubev A.P. (2004) Variability of quantitative parameters of growth and reproduction in Artemia (Crustacea, Anostraca) as a factor of adaptation to environmental conditions and a mechanism for transforming life cycles. Artemia biodiversity in the newly independent states: current global resources and their sustainable exploitation. Tyumen, Siberian Research Institute of Fisheries (Sibrybniiproekt), p. 105-115 (in Russian)]

Иванова М.Б. (1985) Продукиия планктонных ракообразных в пресных водах. Л., Институт зоологии АН СССР, 220 c. [Ivanova M.В. (1985) Production of planktonic crustaceans in fresh waters. Leningrad, Institute of Zoology of the USSR Academy of Sciences, 220 p. (in Russian)]

Ковачева Н.П., Литвиненко Л.И., Саенко Е.М., Жигин А.В., Кряхова Н.В., Семик А.М. (2019) Современное состояние и перспективы развития аквакультуры артемии в России. Труды ВНИРО, 178: 150-171 [Kovacheva N.P., Litvinenko L.I., Saenko E.M., Zhigin A.V., Kryahova N.V., Semik A.M. (2019) Current state and prospects of aquaculture artemia in Russia. Trudy VNIRO, 178: 150-171 (in Russian)]

Курочкин В.Ю., Федоров А.А., Хорошавина Е.И., Волкова Н.А. (2014) Природные ресурсы озера Медвежье Курганской области, вопросы их формирования, комплексного использования и охраны. Курортная медицина, 4: 8-13 [Kurochkin V.Yu., Fedorov A.A., Khoroshavina E.I., Volkova N.A. (2014) Natural resources of Medvezhye Lake in the Kurgan region, their formation, complex use and protection. Resort Medicine [Kurortnaya medicina], 4: 8-13 (in Russian)]

Лаврентьева Г.М., Бульон В.В. (1981) Методические рекомендации по сбору и обработке материалов при гидробиологических исследованиях на пресных водоемах. Фитопланктон и его продукиия. Л., Государственный научно-исследовательский институт озерного и речного рыбного хозяйства, 32 с. [Lavrentieva G.M., Bul'on V.V. (1981) Methodological recommendations for the collection and processing of materials for hydrobiological studies in fresh water bodies. Phytoplankton and its products. Leningrad, State Research Institute of Lake and River Fisheries, 32 p. (in Russian)]

Лакин Г.Ф. (1990) Биометрия. Учебное пособие для биологических спеииальностей вузов. М., Высшая школа, 352 c. [Lakin G.F. (1990) Biometrics. A textbook for biologists. Moscow, Vysshaya shkola, 352 p. (in Russian)]

Лаптева Н.А., Соколова Е.А. (2013) Структурно-функциональные характеристики сообщества микроорганизмов в гипергалинном оз. Сакское. Труды зоологического института РАН, 317(S3): 136-143 [Lapteva N.A., Sokolova E.A. (2013) Structural and functional characteristics of communities of microorganisms in Crimean hyperhaline lake Sakskoye. Proceedings of the Zoological Institute RAS [Trudy Zoologicheskogo instituta RAN], 317(S3): 136-143 (in Russian)]

Литвиненко А.И., Литвиненко Л.И., Соловов В.П., Ясюченя Т.Л., Веснина Л.В. (2002) Meтодические указания по определению Общих Допустимых Уловов (ОДУ) ичист жаброногого рачка Artemia. Тюмень, СибрыбНИИпроект, 25 с. [Litvinenko A.I., Litvinenko L.I., Solovov V.P., Yasyuchenya T.L., Vesnina L.V. (2002) Guidelines for determining the Total Allowable Catches (TAC) of cysts of the crustacean Artemia (Branchiopoda). Tyumen, Siberian Research Institute of Fisheries (Sibrybniiproekt), 25 p. (in Russian)]

Литвиненко Л.И., Литвиненко А.И., Бойко Е.Г. (2009) Артемия в озерах Западной Сибири. Новосибирск, Наука, 304 с. [Litvinenko L.I., Litvinenko A.I., Boyko E.G. (2009) Artemia in the lakes of Western Siberia. Novosibirsk, Nauka, 304 p. (in Russian)] 
Литвиненко Л.И., Литвиненко А.И., Бойко Е.Г., Куцанов К.В. (2019) Влияние промысла цист артемии на лечебные грязи гипергалинных озер. XII Съезд Гидробиологического общества при РАН: тезисы докладов. Петрозаводск, КарНЦ РАН, с. 306-307 [Litvinenko L.I., Litvinenko A.I., Boyko E.G., Kutsanov K.V. (2019) Influence of Artemia cyst harvesting on therapeutic mud of hyperhaline lakes. XII Congress of the Hydrobiological Society of the Russian Academy of Sciences: Abstracts. Petrozavodsk, KarSC RAS, p. 306-307 (in Russian)]

Методические рекомендации по оченке и прогнозированию рекомендованного объема добычи (вылова) артемии (2019) Литвиненко Л.И., Бизиков В.А., Ковачева Н.П., Саенко Е.М., Веснина Л.В., Куцанов К.В., Семик А.М., Паршин-Чудин А.В. (составители) ВНИРО, 49 c. [Methodological recommendations for evaluating and predicting the recommended volume of production (catch) of Artemia (2019) Litvinenko L.I., Bizikov V.A., Kovacheva N.P., Saenko E.M., Vesnina L.V., Kutsanov K.V., Semik A.M., Parshin-Chudin A.V. (compilers) Moscow, Russian Federal Research Institute of Fisheries and Oceanography (VNIRO), 49 p. (in Russian)]

Матмуратов С.А., Стуге Т.С., Лопатин О.Е. (2004) Распространение и развитие артемии в соляных озерах Прииртышья республики Казахстан. Биоразнообразие артемии в странах СНГ: современное состояние ее запасов и их использование. Тюмень, СибрыбНИИпроект, c. 41-51 [Matmuratov S.A., Stuge T.S., Lopatin O.E. (2004) Distribution and development of brine shrimp in salt lakes at Pryirtysh region in Kazakhstan Republic. Artemia biodiversity of in the newly independent states: current global resources and their sustainable exploitation. Tyumen, Siberian Research Institute of Fisheries (Sibrybniiproekt), p. 41-51 (in Russian)]

Михеева Т.Н. (1970) Оценка продукционных возможностей единицы биомассы фитопланктона. Биопродуктивность эвтрофного озера. М., Наука, с. 50-70 [Mikheeva T.N. (1970) Evaluation of the production capacity of a unit of phytoplankton biomass. Bioproductivity of the eutrophic lake. Moscow, Nauka, p. 50-70 (in Russian)]

Оборин М.С., Завьялова О.Г., Бакулина Ю.С. (2012) Системно-диалектическая методология как инструмент анализа курортно-рекреационных зон (на примере окрестностей озера Медвежье Курганской области). Географический вестник, 2(21): 84-92 [Oborin M.S., Zavylova O.G., Bakulina U.V. (2012) System-dialectic methodology as the tool of the analysis of recreaction-resort zones (on the example of vicinities of lake Bear the Kurgan region). Geographical Bulletin [Geograficheskii vestnik], 2(21): 84-92 (in Russian)]

Озеро Медвежье: биологическая продуктивность и комплексное использование природных ресурсов гипергалинного озера (2001) Литвиненко А.И. (ред.) Тюмень, СибрыбНИИпроект, $64 \mathrm{c}$. [Medvezhye Lake: biological productivity and integrated use of natural resources of hypersaline lake. (2001) Litvinenko A.I. (ed.) Tyumen, Siberian Research Institute of Fisheries (Sibrybniiproekt), 64 p. (in Russian)]

Печень Г.А. (1968) Графический метод расчета продукции. Методы определения продукции водных животных. Минск, Вышэйшая школа, с. 115-120 [Pechen' G.A. (1968) Graphical method for calculating production. Methods for determining the production of aquatic animals. Minsk, Vysheishaya shkola, p. 115-120 (in Russian)]

Руководство по химическому анализу поверхностных вод суши (1977) Семенов А.Д. (ред.) Л., Гидрометеоиздат, 541 c.[Guide to chemical analysis of land surface waters (1977) Semenov A.D. (ed.) Leningrad, Gydrometeoizdat, 541 p. (in Russian)]

$$
-365-
$$


Соловов В.П., Студеникина Т.Л. (1990) Рачок артемия в озерах Западной Сибири: морфология, экология, перспективы хозяйственного использования. Новосибирск, Наука, 81 с. [Solovov V.P., Studenikina T.L. (1990) Artemia crustacean in the lakes of Western Siberia: morphology, ecology, prospects for economic use. Novosibirsk, Nauka, 81 p. (in Russian)]

Терешенкова Т.В. (1983) Особенности продуциирования фитопланктона малых удобряемых озер Северо-Запада. Автореф. дис...канд. биол. наук. Л., ГосНИОРХ, 22 с. [Tereshenkova T.V. (1983) Features of phytoplankton production in small fertilized lakes of the North-West. Abstract of the thesis of the Candidate of Biological Sciences. Leningrad, State Research Institute of Lake and River Fisheries, 22 p. (in Russian)]

Хмелева Н.Н. (1968) Затраты энергии на дыхание, рост и размножение у Artemia salina (L.). Биология моря, 15: 71-98 [Khmeleva N.N. (1968) Energy consumption for respiration, growth and reproduction in Artemia salina (L.). Marine Biology [Biologiya morya], 15: $71-98$ (in Russian)]

Чепуркина М.А., Гилева Е.А., Прусинска М., Кольман Р. (2014) Использование метода обогащения науплиусов артемии в осетроводстве. Вестник рыбохозяйственной науки, 1(4(4)): 7890 [Chepurkina M.A., Gilyeva E.A., Prusinska M., Kolman R. (2014) The use of method of live feed enrichment in sturgeon aquaculture. The Bulletin of Fisheries Science [Vestnik rybohozyaistvennoi nauki], 1(4(4)): 78-90 (in Russian)]

Belovsky G.E., Stephens D., Perschon C., Birdsey P., Paul D., Naftz D., Baskin R., Larson C., Mellison C., Luft J., Mosley R., Mahon H., Van Leeuwen J., Allen D.V. (2011) The Great Salt Lake ecosystem (Utah, USA): long term data and a structural equation approach. Ecosphere, 2(3): 33

Bhargava S.C., Jakher G.R., Saxena M.M., Sinha R.K. (1987) Ecology of Artemia in Didwana salt lake (India). Artemia research and its applications. Volume 3. Sorgeloos P., Bengtson D.A., Decleir W., Jaspers E. (eds.) Belgium, Universa Press, Wetteren, p. 127-133

De Los Santos C.S., Sorgeloos P., Lavina E., Bernardino A. (1979) Successful inoculation of Artemia and production of cysts in manmade salterns in the Philippines. Abstracts of International Symposium on the Brine Shrimp Artemia salina. Belgium, State University of Ghent, p.47

Dutrieu J. (1960) Observations biochimiques et physiologiques sur le developpement d'Artemia salina Leach. Archives de zoologie expérimentale et générale, 99: 1-134

Golubkov M.S. (2012) Primary production of plankton and decomposition of organic matter in saline lakes of the Crimea peninsula. Inland Water Biology, 5(4): 322-327

Great Salt Lake. An overview of Change (2002) J. Wallace Gwynn (ed.) Salt Lake City, Utah Department of Natural Resources, $584 \mathrm{p}$.

Lenz P.H. (1987) Ecological studies on Artemia: a review. Artemia research and its applications. Volume 3. Sorgeloos P., Bengtson D.A., Decleir W., Jaspers E. (eds.) Belgium, Universa Press, Wetteren, p. 5-18

Leonova G.A., Bobrov V.A., Bogush A.A., Bychinskii V.A., Anoshin G.N. (2007) Geochemical characteristics of the modern state of salt lakes in Altai krai. Geochemistry International, 45(10): 10251039

Litvinenko L.I., Litvinenko A.I., Boiko E.G. (2016) Brine shrimp Artemia in Western Siberia lakes. Novosibirsk, Nauka, 295 p.

Litvinenko L.I., Litvinenko A.I., Boiko E.G., Kutsanov K.V. (2015) Artemia cyst production in Russia. Chinese Journal of Oceanology and Limnology, 33(6): 1436-1450 
Post F.J., Youssef N.N. (1977) A prokaryotic intracellular symbiont of the Great Salt Lake brine shrimp Artemia salina (L.). Canadian Journal of Microbiology, 23(9): 1232-1236

Prokopiev S.I., Ovchinnikova T.E., Vasiliev O.F. (2010) Thermodynamic characteristics of water in natural water bodies with a high mineralization. Izvestiya, Atmospheric and Oceanic Physics, 46(2): 256-260

Romankevich E.A., Vetrov A.A. (2013) Masses of carbon in the Earth's hydrosphere. Geochemistry International, 51(6): 431-455

Schrehardt A. (1987) A scanning electron-microscope study of the post-embryonic development of Artemia. Artemia research and its applications. Volume 1. Sorgeloos P., Bengston D.A., Decleir W., Jaspers E. (eds.) Wetteren, Universa Press, p. 5-33

Shadrin N., Anufriieva E. (2012) Review of the biogeography of Artemia Leach, 1819 (Crustacea: Anostraca) in Russia. International Journal of Artemia Biology, 2(1): 51-61

Shadrin N., Anufriieva E., Galagovets E. (2012) Distribution and historical biogeography of Artemia leach, 1819 (Crustacea: Anostraca) in Ukraine. International Journal of Artemia Biology, 2(2): $30-42$

Shadrin N., Yakovenko V., Anufriieva E. (2019) Suppression of Artemia spp. (Crustacea, Anostraca) populations by predators in the Crimean hypersaline lakes: A review of the evidence. International Review of Hydrobiology, 104(1-2): 5-13

Sorgeloos P., Lavens P., Leger Ph., Tackaert W., Versichele D. (1986) Manual for the culture and use of brine shrimp in aquaculture. Belgium, State University of Ghent, 319 p.

Tackaert W., Sorgeloos P. (1991) Semi-intensive culturing in fertilized ponds. Artemia biology. Browne R.A., Sorgeloos P., Trotman C.N.A. (eds.) CRC Press, p. 287-315

UT-DWR (2014) Great Salt Lake Ecosystem Project: Historical brine shrimp harvest data. http:// wildlife.utah.gov/gsl/harvest/historic_harvest_data.php.

Vanhaecke P., Siddall S.E., Sorgeloos P. (1984) International study on Artemia. XXXII. Combined effects of temperature and salinity on the survival of Artemia of various geographical origins. Journal of Experimental Marine Biology and Ecology, 80(3): 259-275

Van Stappen G., Litvinenko L., Litvinenko A., Boyko E., Marden B., Sorgeloos P. (2009) A survey of Artemia resources of Southwest Siberia (Russian Federation). Reviews in Fisheries Science, 17(1): $117-148$

Wear R.G., Haslett S.J. (1987) Studies on the biology and ecology of Artemia from Lake Grassmere, New Zealand. Artemia research and its applications. Volume 3. Sorgeloos P., Bengtson D.A., Decleir W., Jaspers E. (eds.) Belgium, Universa Press, Wetteren, p. 101-126 